\title{
Propagation material borne fungus pathogens causing early stock decay in vineyards
}

\author{
Dula, T. \\ Eger, Eszterházy tér 9., Hungary, Tel.: +36 20539 1678; e-mail: terezia@dulabor.hu
}

\begin{abstract}
Summary: A decline, a slow or sudden decay of vine trunks can occur in any phase of trunk life. In senescent or old plantages the increase in trunk decay is quite common but it is unacceptable in young plantage in their best production years. All over the world as well as in Hungary, a drastic decay of young trunks in nurseries and new plantages have caused panic in the past decades. From among the numerous fungal pathogens which are responsible for considerable financial and yield losses and threaten stock vigour Petri disease, esca and Black foot are the most important. In young decaying plants the fungal species Phaeomoniella chlamydospora, Phaeoacremonium spp. and Cylindrocarpon spp. were the most frequent while other fungi causing different trunk diseases, cancer or decay, like Eutypa lata, Botryosphaeria spp. and Fomitiporia mediterranea were also found. The most important infection source is the infected propagation material. Infection is systematic, the disease process is latent, diseased plants cannot be cured, thus, prevention is the only answer to the challenge.
\end{abstract}

Keywords: decay of young trunks, young esca, Petri-disease, esca, esca proper, black foot disease

Esca is a complex disease caused by the joint or successive effects of biotic and abiotic factors considering trunk decay these factors can have predisposing (e.g. virus infection, senescence, climatic changes), eliciting (e.g. drought, precipitation, frost) or aggravating effects (e.g. cancer pathogens, virus infection, wood tissue diseases) (Vajna, 1998; Bruccini et al., 2008).

Scientists agree that esca - though known for a long time has turned out to be a new kind Phylloxera-like epidemic (Morton, 1995; Acheck et al., 1998; Graniti et al., 2000; Wait \& Morton, 2007). Esca is present in old and young bearing vineyards, in rootstocks and scions alike. In Hungary the number of stocks with symptoms has increased since 2000 (Apponyi et al., 1999; Mikulás \& Lázár, 2001; Dula, 2003; Mikulás et al., 2004; Dula, 2004, 2007) (Fig. 1-2.)

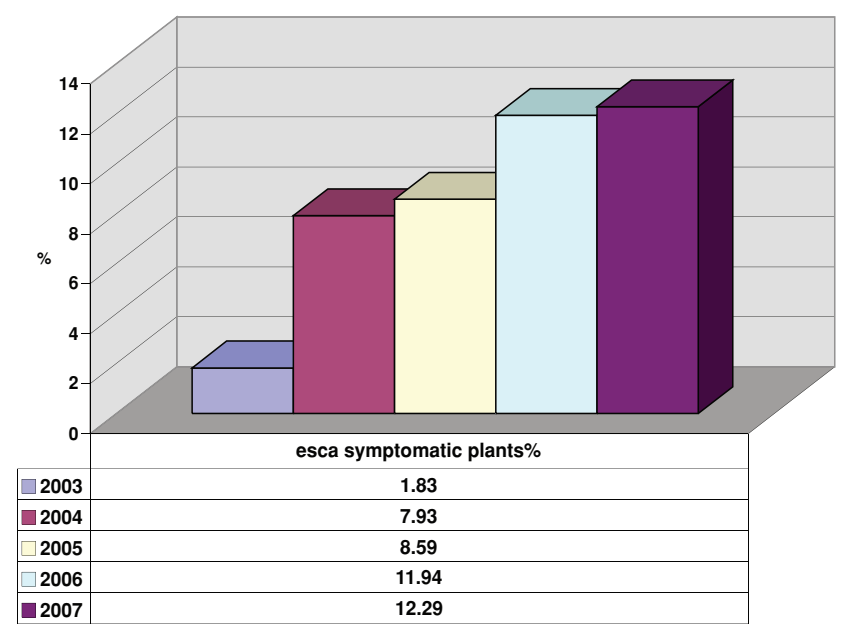

Fig. 1. Frequency of esca symptomatic plants Hungary 2003-2007
Of the 3 fungi responsible for esca Phaeomoniella chlamydospora (Pch) and Phaeoacremonium aleophilum (Pal) causing tracheomycosis are the most important (Mugnai et al., 1999; Surico et al., 2008). These two pathogens are responsible for the syndrome of brown stripe diseases, Petri-disease (of Black goo) and young esca in rooted canes and grafts.

On plants grown in nurseries no external symptoms can be observed, only changes in the internal tissue reveal infection. In the vertical section of rootstocks and scions long, brownish-black stripes start from the bottom or place of grafting, in the cross-section tiny black spots, frequency in ring form and rubber-like, dark secretion appear round the pith (Photos 1, 2, 3). In the spread of the disease the latently infected base material plays can an important part (Acheck et

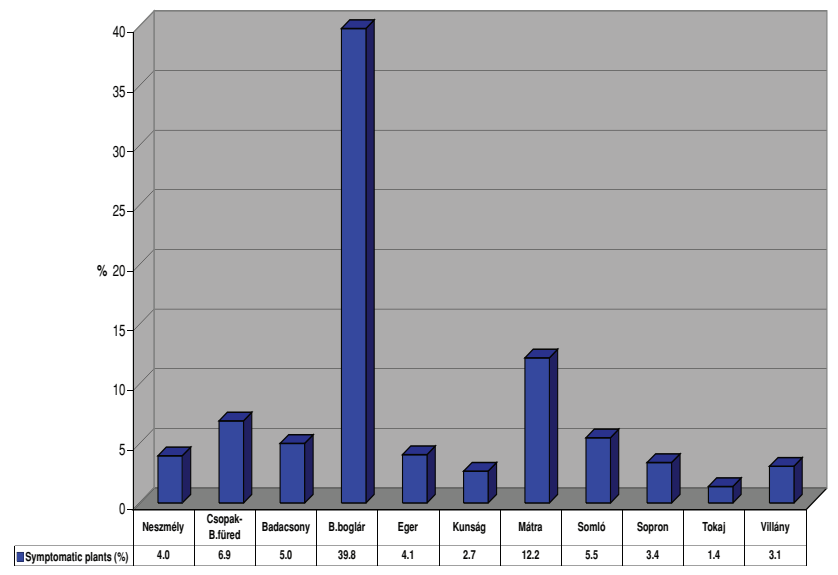

Fig. 2. Frequency of esca symptomatic plants on the wineregions in Hungary Average of three years (2003-2005) 


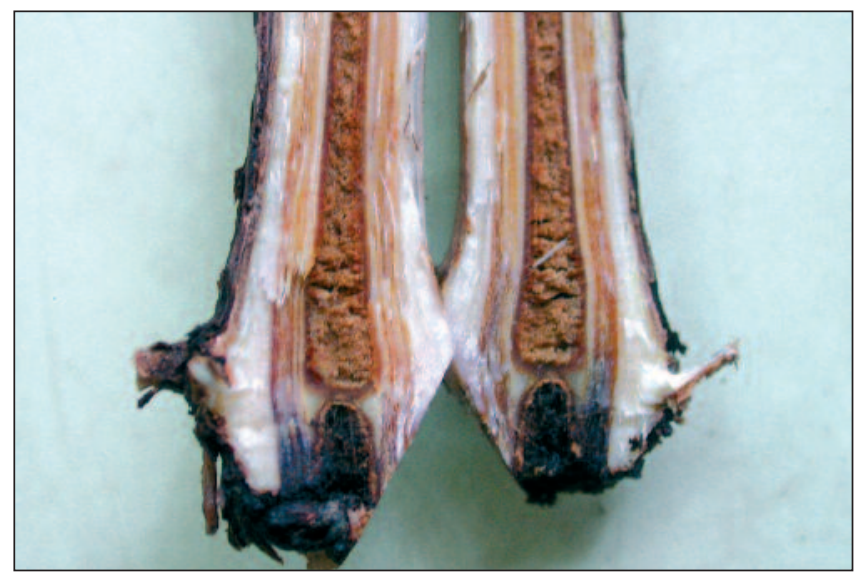

Photo 1. Brown tissue streaking in rootstock vascular system

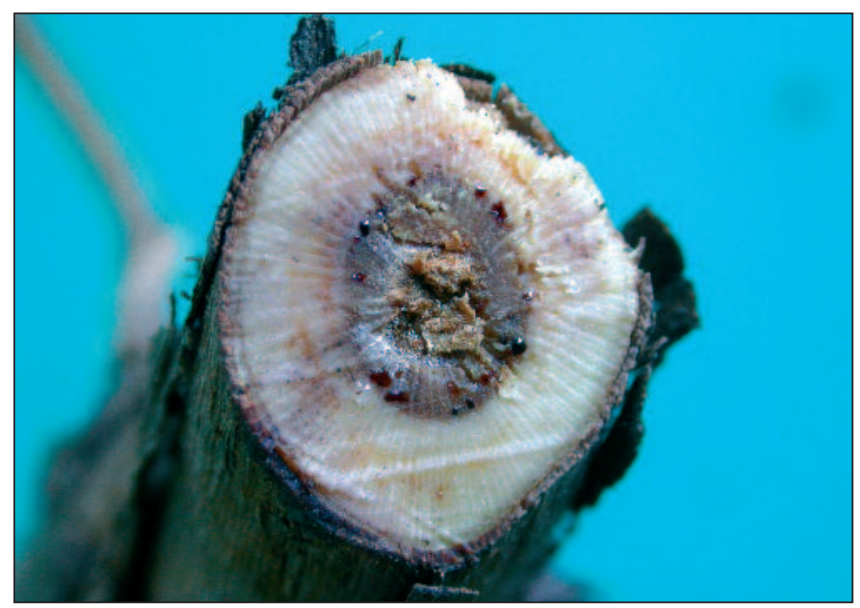

Photo 2. Gum-like, dark exudate in the vascular system

al., 1998; Aroca et al., 2010; Graniti et al., 2000; Morton, 1995; Mugnai et al., 1999; Surico et al., 2008; White \& Morton, 2007; Whiteman et al., 2007).

Petri-disease appears in very young, 1-8-years-old plantages (Ferreira et al., 1999; Morton, 1995; Mugnai et al., 1999; Pascoe \& Cottral, 2000; Scheck et al., 1998). Stunted growth, slightly chlorotic leaves are typical external symptoms with dark pith tissue, black spots or ring round the pith and rubber-like dark secretion in the inner tissue (Photo 3).

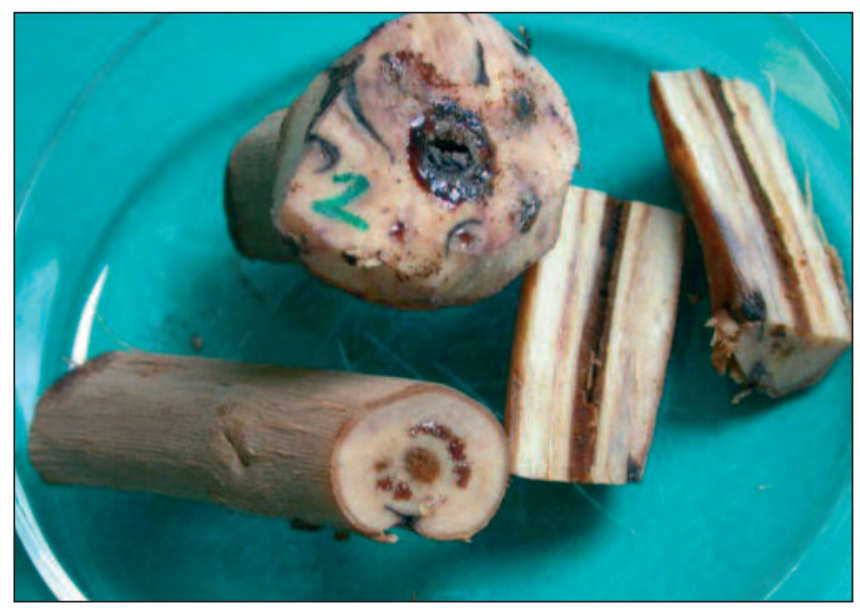

Photo 3. Petri-disease: streaking and gum-like, dark exudate
The vascular "young esca" disease, newly named as vine leaf streaking (Surico, 2009), is caused by P. chlamidospora and often also by P. aleophilum (Mugnai et al., 1998; Surico et al., 2008). Young esca can appear in 2-4-years-old vineyards. Tiny chlorotic spots are visible in the internodes and later typical tiger stripes can form (Photo 4). Leaf symptoms are caused by the phytotoxins produced by the fungi (Evidente et al., 2000; Sparapano et al., 2000, Abou Mansour et al., 2004). Symptoms in the wood tissue are similar to those found in grafts and the Petri-disease but here the brownish-red wood tissue necrosis can have a larger extent (Photo 5).

In connection to the esca complex another fungus must be mentioned though it does not infect through propagation material. Fomitiporia mediterranea (Fmed) is a Basidiomycetes species including white decay in the vine

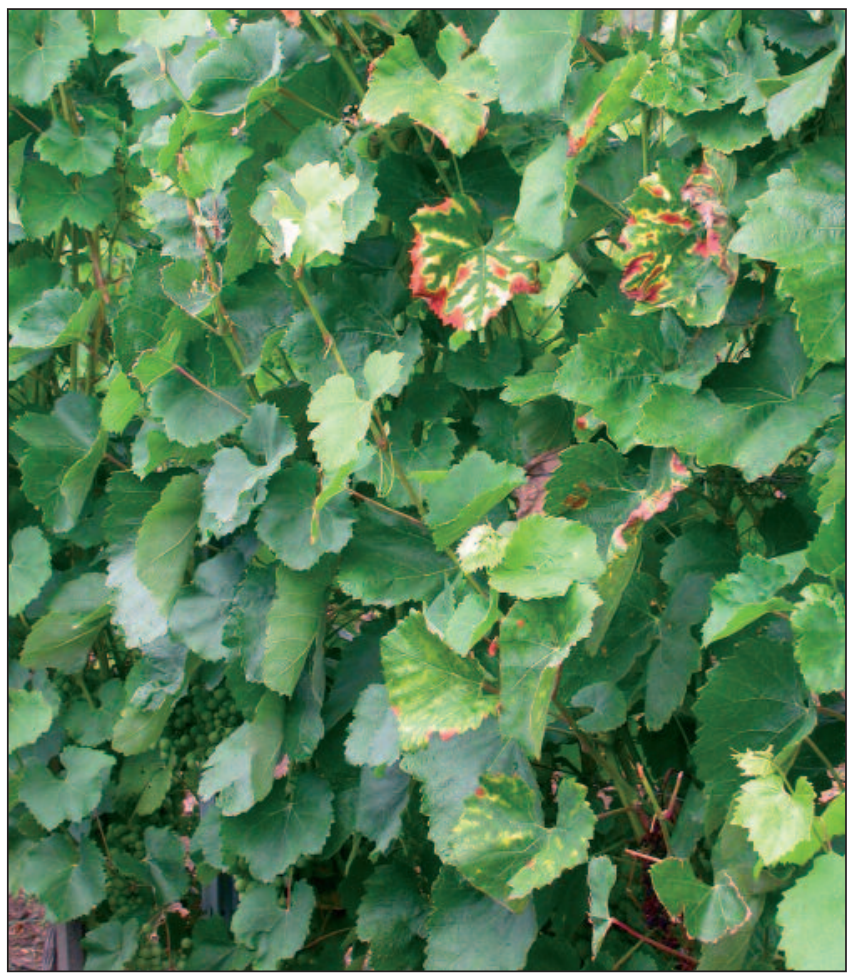

Photo 4. Young esca leaf symptoms in 4-years-old Furmint stock

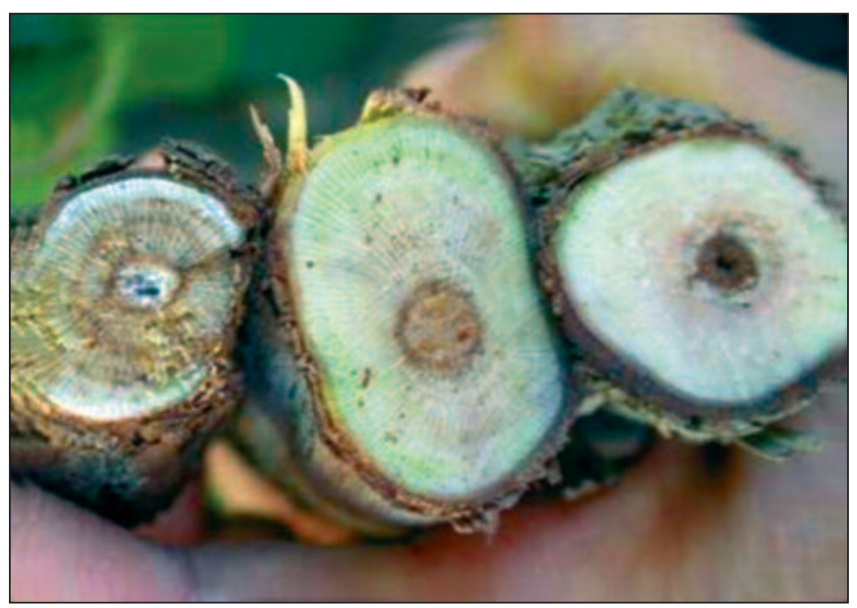

Photo 5. Pch infection symptom in 4-years-old Furmint 
trunk. It has numerous other host plants. In Europe trunk decay is mostly due to Fmed but in other districts some other species causing decay could also be isolated (Fischer, 2006; White et al., 2010; Véghelyi et al., 2001). In very young, 2-4years-old trunks white rot can appear alone. In these stocks spots, esca symptoms are never found (Edwards et al., 2001) but according to the extent of wood tissue rot, the foliage has a pale colour (Dula, non published).The pathogen often invades the stock through wounding. The infected wood tissue is yellowish-white, spongy, a dark border separates it from the healthy tissue (Larignon \& Dubos, 1997) (Photo 6).

In the traditional sense the name "esca" means white decay. We speak of "proper esca" when leaf symptoms caused by the two vascular pathogens and by white rot are found in the same stock. This syndrome is mostly observed in older rootstocks in production (Photos $7,8,9)$. In the

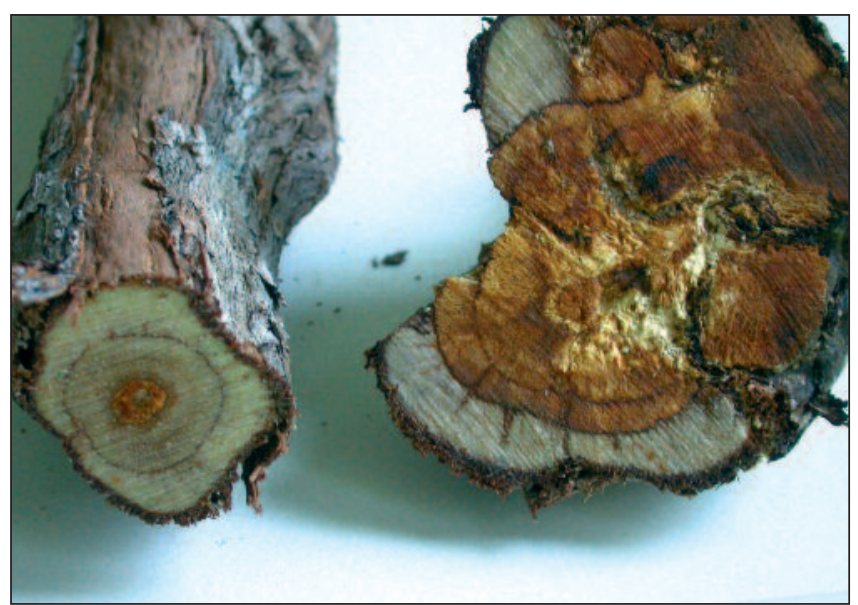

Photo 6. White decay (Fmed) in 4-years-old Furmint

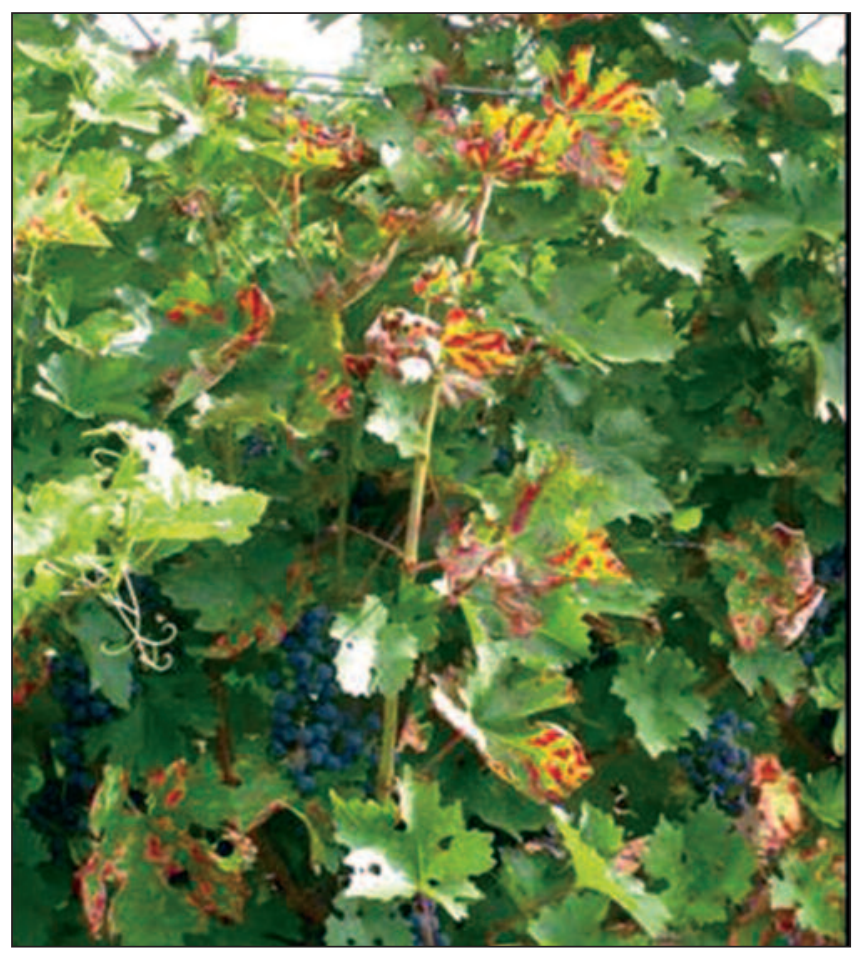

Photo 7. Typical esca tiger-stripe symptom diseased plants the pathogens of the two vascular diseases and those of white rot are present. It is important to stress that the pathogens of the vascular disease are propagated exclusively through the propagation material, while spore of the white rot fungus infect plants through wounding.

In stocks infected by vascular disease pathogens $P c h, P a l$ some other pathogens damaging wood tissue could be found: Botryosphaeriaceae spp., Diatrypaceae species (like Eutypa lata), Phomopsis viticola (Lehoczky, 1972, Lehoczky \& Moller, 1979). Recently Botryosphaeriaceae species could be isolated from nursery material (Spagnola et al., 2011).

Pch has only been detected in vine but it is quite common in vine regions of the world (Gramaje et al., 2011). Of different host plants 34 Pheoacremonium species have been isolated of which 25 species from vine with or without symptoms (Mostert et al., 2006). In a global survey in 2007 numerous new Phaeo species were found, also a Phaeoacremonium hungaricum (Essakhi et al., 2008) in Tokajhegyalja, Hungary. At present $\mathrm{Pal}$ is the most common in vineyards. While the sexual form of $P c h$ is still unknown, the sexual form of Pal, Togninia minima, was found in

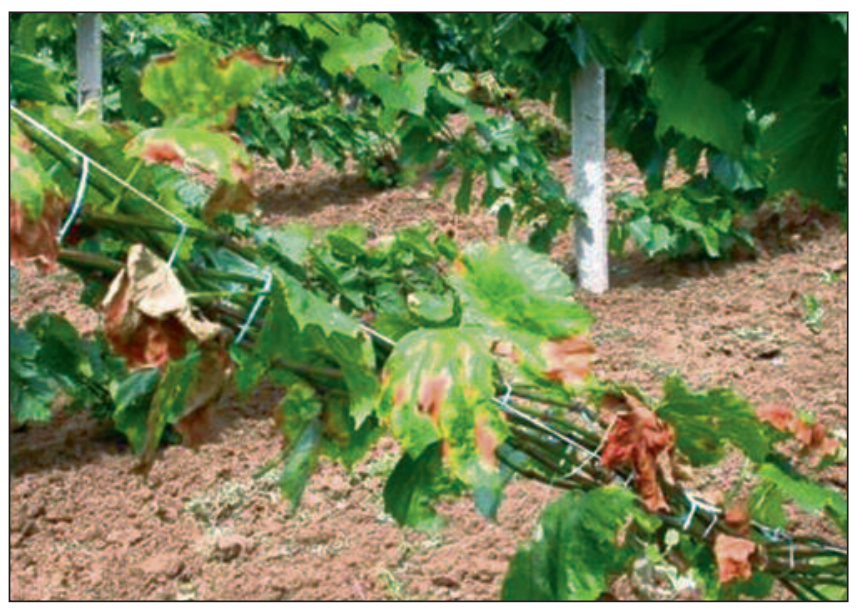

Photo 8. T 5C rootstock with esca symptom

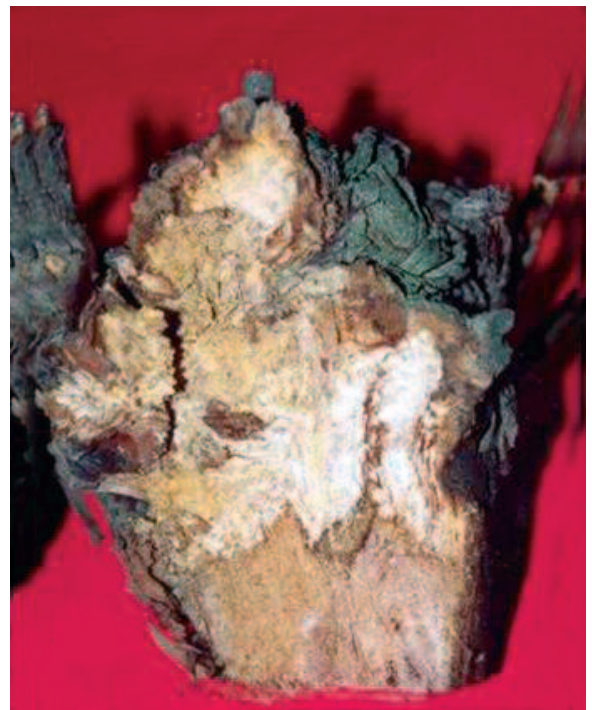

Photo 9. White decay in $\mathrm{T} 5 \mathrm{C}$ rootstock 
several places (Monstert et al., 2003; Pascoe et al., 2004; Eskalen et al., 2005). Infectious spores of both species are found o the surface rootstocks and scions. They invade the xylem through wounding in the bottom part caused by disbudding and grafting. Infection can occur in any phase of the grafting operation as wounds cannot be avoided, but the most vulnerable phases are soaking and grafting of the rootstocks and scions (Fourie \& Halleen, 2002, 2003; Edwards et al., 2004; Aroca et al., 2009a). Though Pch can be detected from infected plant residues in the soil the infectivity of pathogens isolated from naturally infected soil has not been proved yet (Roonay et al., 2001; Fourie et al., 2004; Tello \& Gonzalez, 2010). The disease causes considerable loss in rooting in nurseries. In rooted propagation material the infection is latent, symptoms appear 1-2 years later (Edward et al., 2001, 2004; Zanzotto et al., 2001; Di Marco \& Osti, 2007). Growth is weak, the numerous missing stocks must be replaced. In later years repeated yield losses and increased stock death aggravate the financial situation of growers.

Black foot disease: Cylindrocarpon (anamorf Neonectria) species are responsible for the black foot disease of the vine (Grasso, 1984; Rego et al., 1998, Maluta \&Larignon, 1991; Rego et al., 2001, 2006; Halleen et al.,

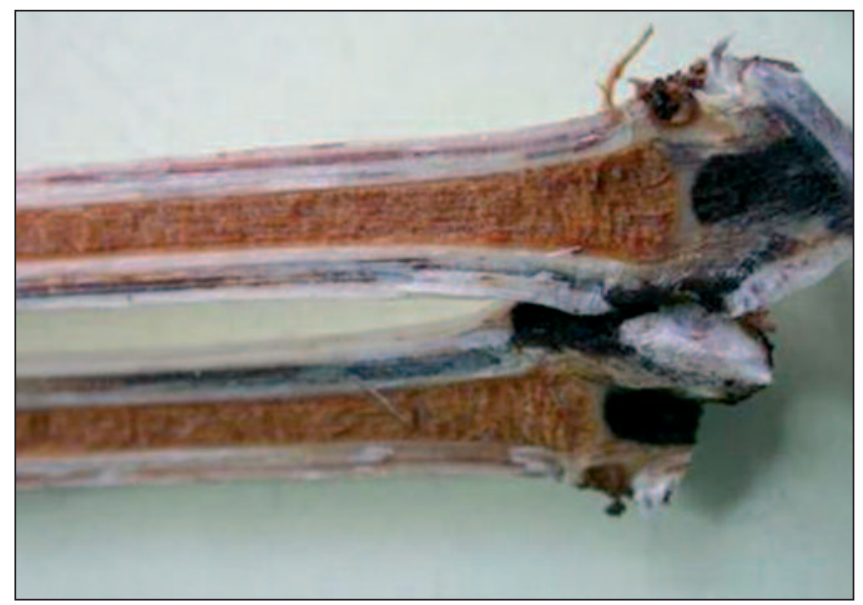

Photo 10. Cyl infection symptoms in the bottom part of rootstock

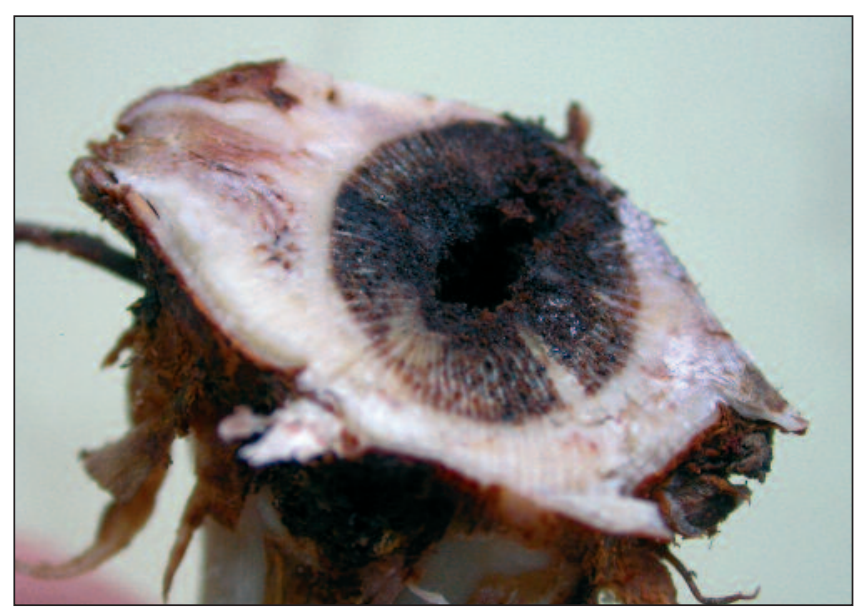

Photo 11. Cyl symptom in rootstock

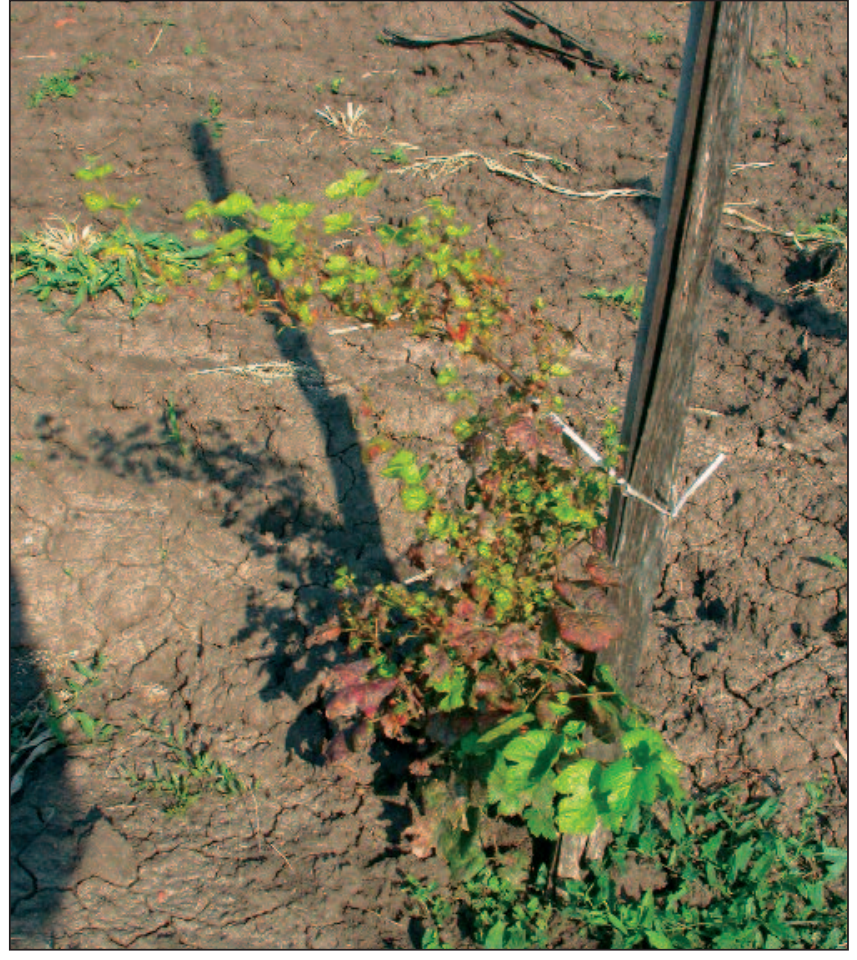

Photo 12. Severe, early stock decay in 4-years-old merlot

2006; Alaniz et al., 2007; Scheck et al., 1998). According to recent research it is caused by the joint infection of several species. The primary pathogens are: Cylindrocarpon (Cyl. liriodendri MacDon \& Butler), Cyl. destructans (Zins.) Scholten and Cyl. macrodidynum (Schroers, Halleen \& Crous) as well as Campylocarpon (Campyl. fasciculare and Campyl. pseudofasciculare (Alaniz et al., 2007, 2009; Halleen et al., 2006b).

These species are present in the most important vine regions of the world. They can often be isolated in nurseries from rooted canes and grafts (Rego et al., 2000; Fourie \& Halleen, 2001). Infection is initiated from the soil. Micro- and macro-conidia, clamydospores or mycelium fragments can also infect roots (Halleen et al., 2003; Probst et al., 2009).

Principal symptoms: necrotic rot of the root crown, sunken spots on the root, root decay, longitudinal black necrosis and streaking starting from the bottom of the xylem (Photos 10-11), slow growth, short internodes, stunted shoots, small leaves, chlorosis and necrosis between veins (Photo 12). In vineyards planted with infected nursery material considerable stock decay can occur in a short time. Replacement costs burden growers heavily. The widely used glyphosate herbicide aggravates the situation in watery, wet places visibly (Whitelaw-Weckert, 2010).

\section{Prevention of fungal infections}

It is generally accepted that the drastic increase in fungal diseases causing early decay in stocks is due to the insufficient hygienic conditions during the production of the propagation material. There are no effective chemical 
treatments against latent pathogens. Tests were to treat diseased stocks with symptoms with fungicides injected into trunk during dormancy. The failure proved that diseased plants cannot be cured (Di Marco et al., 1997; Darrieutort \& Lecompte, 2007; Dula et al., 2007). Thus, prevention is of primary importance. In general opinion high quality, healthy, pathogen-free propagation material must be available. In the first step rootstocks and basic vineyards must be controlled, diseased plants marked, removed and annihilated (Lehoczky, 1984). In the next step rootstocks and shoots collected for rooting and grafting must be disinfected on the surface as infectious spores adhere to the surface. Numerous biological substances and fungicides have been tested to kill the spores on the surface of canes during the development of the propagation material. Some reliable results could be obtained by hot water (HWT), Trichoderma spp. and some chemicals. Hot water treatment (at $50{ }^{\circ} \mathrm{C}$ for $30-45$ minutes) was tested by several workers with variable success (Crous et al., 2001; Edwards et al., 2004b; Fourie \& Halleen, 2004; Gramaje et al., 2009a; Retief et al., 2005; Rooney \& Gubler, 2001; Waite, 1998; Whiting et al., 2001). Hot water weakens the vitality of the pathogens efficiently in dormant canes. The methods is economical as large quantities of material (rootstock, spurs) can be treated. It is advisable to use it prior to the cold storage of canes. After the heat treatment canes should be recooled gradually to avoid sudden heat stress and bud damage. The individual heat sensitivity of varieties should also be considered. Pinot noir is the most sensitive, Chardonnay, merlot and Riesling are moderately sensitive while Cabernet sauvignon is the most tolerant to heat treatment (Waite et al., 2001; Crocker et al., 2002; Waite \& May, 2005; Waite \& Morton, 2007). The effect of heat treatment is of short duration. The treated plants can be infected readily in the field by $C y l$ or $P c h$. It should be combined with fungicides (e.g. cyrocozanol followed by HWT) for lasting effect.

The antagonistic fungus Trichoderma is a widely used biological tool to fight tracheomicosis pathogens (Hunt, 2001; Howell, 2003). Tr. has several advantages: by colonizing the root sphere it prevents root infection due to its antagonistic and competitive effect, increases stress tolerance and resistance in stocks and increases the root mass (Fourie et al., 2001; Hunt et al., 2001; Di Marco et al., 2004; Di Marco \& Osti, 2007). Trichoderma is most effective in its natural sphere, in soil treatment. Rooted canes and grafts should be soaked or thouroughly watered when planted in nurseries or plantages.

Of the chemicals, benomyl, thiophanat methyl, thiramot with a broad active spectrum and absorption proved to be best in controlling Pch, Pal and Cyl (Fourie \& Halleen, 2004, 2005; Eskalen et al., 2007; Gramaje et al., 2009b; Tello \& Gonzales, 2010; Alaniz et al., 2011).

\section{References}

Abou-Mansour, E., Couché, E. \& Tabacchi, R. (2004): Do fungal naphthalenones have a role in the development of esca symptoms? Phytopathologia Mediterranea, 43: 75-82.
Acheck, H., Vasquez, S. J., Fogle, D. \& Gubler, W. D. (1998): Grape growers report losses to blackfoot and grapevine decline. California Agriculture, 52: 19-23.

Alaniz, S., León, M., Vicent, A., García-Jiménez, J., AbadCampos, P. \& Armengol, J. (2007): Characterization of Cylindrocarpon species associated with Black Foot Disease of grapevine in Spain. Plant Disease, 91: 1187-1193.

Alaniz, S., Adab-Campos, P., Garcia-Jimenez, J. \& Armengol, J. (2011): Evaluation of fungicides to control Cylindrocarpopn liriodendri and Cylindrocarpon macrodidinum in vitro, and their effect during the rooting phase in the grapevine propagation process. Crop Protection, 30: 489-494.

Aroca, Á., Gramaje, D., Armengol, J. \& Raposo, R. (2009): A new method for detecting Phaeomoniella chlamidospora and Phaeoacremonium species in grapevine plants. Phytopathologia Mediterranea 48: 163 (abstract)

Aroca, Á., Gramaje, D. Armengol, J., García-Jiménez, J. \& Raposo, R. (2010): Evaluation of the grapevine nursery propagation process as a source of Phaeoacremonium spp. and Phaeomoniella chlamydospora and occurence of trunk disease pathogens in rootstock mother vines in Spain. European Journal of Plant Pathology, 126: 165-174.

Aponyi I., Rábai, A. \& Mikulás, J. (1999): Early dieback of grapevine stocks in Hungary. $1^{\text {st }}$ International Workshop on grapevine Trunk Diseases, Abstracts, 19

Braccini P., Calcarano, F., Di Marco, S., Marchi, G., Mugnai, L., Peduto, S., Orlanidi, S., Osti, F. \& Surico, G. (2005): Relation of esca foliar symptoms to rainfall and rainfall-related parameters. Phythopathologia Mediterranea, 44: 107.

Crocker J., Waite, H., Wright, P. \& Fletcher, G. (2002): Source area management: avoiding cutting dehydration and good nursery management may be the key to successful water treatment. The Australian and New Zealand Grapegrower and Winemaker, Annual Technical Issue, 461a: 33-37.

Crous, P. W., Swart, L. \& Coertze, S. (2001): The effect of hot water treatment on fungi occuring in apparently healthy grapevine cuttings. Phytopathologia Mediterranea 40: S464S466 39

Darrieutort G. \& Lecompte P. (2007): Evaluation of a trunk injection technique to control grapevine wood diseases Phytopathologia Mediterranea 46: 50-57

Di Marco, S., Osti, F. \& Cesari, A. (2004): Experiment on the contronl of esca by Trichoderma. Phytopathologia Mediterranea, 43: 108-115.

Di Marco, S. \& Osti, F. (2007): Application of Trichoderma to prevent Phaeomoniella chlamydospora infection in organic nurseries. Phytopathologia Mediterranea, 46: 73-83.

Di Marco S., L. Draghetti, P. Larignon \& A. Brunelli (1993):Control of grapevine wood decay fungi by a "syringe" injection application technique. Proceedings of the II International Symposium on Pesticides Application, Strasbourg (France) 22-24 September 1993, ANPP Annales 2, 595-602.

Dula T. (2003): Szőlőleromlás, korai tőkeelhalás. ("grapevine decline"). Gyakorlati Agrofórum, 14 (5): 17-25.

Dula T. (2004a): Gondolatok a korai tőkeelhalásról. Magyar Szőlőszaporító 2. (1): 9-10.

Dula T. (2004b): Esca és Petri betegség. Gyakorlati Agrofórum 15 (Extra 7.) 12-15. 
Dula T., Kappes E.M., Horvath A. \& Rabai A (2007): Preliminary trials on treatment of esca-infected grapevines with trunk injection of fungicides. Phytopathologia Mediterranea 46: 91-95.

Edwards, J., Marchi, G. \& Pascoe, I. G. (2001): Young Esca in Australia. Phytopathologia Mediterranea 40 (Supplement): S303-S310

Edwards J., Pascoe, I., Salib, S. \& Laukart, N. (2004a): Phaeomoniella chlamydospora and Phaeoacremonium aleophilum can spread into grapevine canes from trunks of infected mother vines. Phytopathologia Mediterranea, 43: 154 (abstract)

Edwards J., Pascoe, I., Salib, S. \& Laukart, N. (2004b): Hot water treatment of grapevine cuttings reduces incidence of Phaeomoniella chlamydospora in young vines. Phytopathologia Mediterranea, 43: 158-159.

Eskalen, A., Rooney-Latham, S. \& Gubler, W. D. (2001): Detection of Phaeomoniella chlamydospora and Phaeoacremonium spp. from soil and host tissue with nested-PCR. Phytopathologia Mediterranea 40: S480

Eskalen, A., Rooney-Latham, S. \& Gubler, W. D. (2005): Occurence of Togninia fraxinopensyvanica on esca-diseased grapevines (Vitis vinifera) and declining ash trees (Fraxinus latifolia) in Californian vineyards. Plant Disease, 89: 528.

Essakin S., Mugnai L., Crous P.W, Groenewald J.Z. \& Surico G. (2008): Molecular and phenotypic characterisation of novel Phaeoacremonium species isolated from esca diseased grapevines Persoonia 21, 2008: 119-134 www. persoonia.org

Evidente, A., Sparapano, L., Andolfi, A. \& Bruno, G. (2000): Two naphthalenone pentaketides from liquid cultures of Phaeoacremonium aleophilum, a fungus associated with esca of grapevine. Phytopathologia Mediterranea, 39: 162-168. 40.

Ferreira, J. H. S., Van Vyk, P. S. \& Calitz, F. J. (1999): Slow dieback on grapevine in South Africa: stress-related predisposition of young vines for infection by Phaeoacremonium chlamydosporum. South African Journal of Enology and Viticulture 20: 43-46.

Fischer, M. (2006): Biodiversity and geographic distribution of basidiomycetes causing esca-associated white roote in grapevine: a world wide perspective. Phytopathologia Mediterranea 45 (Supplement): S30-S42

Fourie, P. H. \& Halleen, F. (2001a): Field observation of black goo decline and black foot disease of grapevine. In. Proccedings of 11th Congress of The Mediterranean Phythopathological Union and 3rd Congress of Sociedade Portuguesa de Fitopatologia. Universidade de Évora, Évora 17-20 Setembro 288-290.

Fourie, P. H., Halleen, F., Van der Vyve, J. \& Schreuder, W. (2001b): Effect of Trichoderma treatments on the occurence of decline in the roots and rootstoks on nursery grapevines. Phytopathologia Mediterranea, 40: S473-S478

Fourie, P. H. \& Halleen, F. (2002): Investigation on the occurance of Phaeomoniella chlamydospora in canes of rootstock mother vines. Australasian Plant Pathology, 31: 425-426.

Fourie, P. H. \& Halleen, F. (2004): Proactive control of Petri disease of grapevine through treatment of propagation material. Plant Disease, 88: 1241-1245.

Fourie, P. H. \& Halleen, F. (2005): Integrated strategies for proactive management of trunk diseases in nurseries. Phytopathologia Mediterranea, 44: 111. (abstract)

Fourie, P. H. \& Halleen, F. (2006): Chemical and biological protection of grapevine propagation material from trunk disease pathogens. European Journal of Plant Pathology, 116: 255-265.
Gramaje, D., Armengol, J., Salazar, D., López-Cortés, I. \& Garcia-Jiménez, J. (2009a): Effect of hot water treatments above $50{ }^{\circ} \mathrm{C}$ on grapevine viability and survival of Petri disease pathogens. Crop Protection, 28: 280-285.

Gramaje, D., Aroca, Á., Raposo, R., Garcia-Jiménez, J. \& Armengol, J. (2009b): Evaluation of fungicides to control Petri disease pathogens in the grapevine propagation process. Crop Protection, 28: 1091-1097.

Gramaje, D. \& Armengol, J. (2011): Fungal trunk pathogens in the grapevine propagation process: potential inoculum sources, detection, identification and management strategies.Plant Disease (in press, DOI: 10.1094/PDIS-01-11-0025)

Graniti A., Surico, G. \& Mugnai, L. (2000): Esca of grapevine: a disease complex or a complex of diseases? Phytopathologia Mediterranea, 39: 16-20.

Grasso, S. (1984): Infezioni di Fusarium oxysporum e di Cylindrocarpon destructans associate a una moria di giovani piante di vite in Sicilia. Informatore Fitopatologico, 1: 59-63.

Halleen, F., Crous, P.W. \& Petrini, O. (2003): Fungi associated with healthy grapevine cuttings in nurseries, with special reference to pathogens involved in the decline of young vines. Australasian Plant Pathology. 32: 47-52.

Halleen, F., Fourie, P. H. \& Crous, P. W. (2006a): A review of black foot disease of grapevine. Phytopathologia Mediterranea 45 (Supplement): S55-S67

Halleen, F., Schroers, H. J., Groenewald, J. Z. \& Crous, P. W. (2006b): Neonectria liriodendri sp. nov., the main causal agent of black foot disease of grapevines. Studies in Mycology, 55: 227-234.

Howell, C. R. (2003): Mechanisms employed by Trichoderma species in the biological control of plant diseases: The history and evolution of current concepts. Plant Disease, 87: 4-10.

Hunt, J. S., Gale, D. S. J. \& Harvey, I. C. (2001): Evaluation of Trichoderma as bio-control for protection against wood-invading fungi implicated in grapevine trunk diseases. Phytopathologia Mediterranea 40: S485 (abstract)

Lehoczky J., (1972): Dead-arm Disease of Grapevine in Hungary. Acta Phytopatologica Academiae Scientiarum Hungaricae, 7: 401-407.

Lehoczky J. \& W. Moller, (1979): Eutípás rák és tőkeelhalás, a szőlő Magyarországon most felismert súlyos betegsége. Kertgazdaság 11, (2) 37-52.

Lehoczky J., (1984): A szőlőtőkék korai elhalásának okai és a megelőzés teendői. Szölőtermesztés, 3: 17-20.

Maluta, D. R. \& Larignon, P. (1991): Pied noir: mieux vaut prévenir. Vitis 159: 71-72.

Mikulás J., Lázár J., Morvai Sz. \& Rábai A. (2004): A korai tőkeelhalás kutatás legújabb külföldi és hazai eredményei. Gyakorlati Agrofórum Extra, 7: 16-17.

Morton, L. (1995): Mystery diseases hit young vines. Wines and Vines, 76: 46-47.

Mostert, L. Crous, P. W., Groenwald, J. Z., Gams, W. \& Summerbell, R. (2003): Togninia (Calosphaeriales) is confirmed as teleomorph of Phaeoacremonium by means of morphology sexual compatibility, and DNA phylogeny. Mycologia, 95: 646-659.

Mostert, L., Halleen, F., Fourie, P. \& Crous, P. W. (2006): A review of Phaeoacremonium species involved in Petri disease and esca of grapevines. Phytopathologia Mediterranea, 49: S12-S29 
Mugnai, L., Graniti, A. \& Surico, G. (1999): Esca (Black Measles) and brown wood-streaking: two old and elusive diseases of grapevines. Plant Disease, 83: 404-418.

Pascoe, I. G. \& Cottral, E. (2000): Developments in grape trunk disease research in Australia. Phytopathologia Mediterranea, 39: $68-75$.

Pascoe, I. G., Edwards J., Cunninton, J. N. \& Cottral, E. H. (2004): Detection of the Togninia teleomorph of Phaeoacremonium aleophilum in Australia. Phytopathologia Mediterranea, 43: 51-58.

Probst, C. M., Jones, E. E., Ridgway, H. J. \& Jasper, M. V. (2009): Pathogenicity of Cylindrocarpon propagules on grapevine. Phytopathologia Mediterranea, 48: 170-171.

Rabai A., Dula T. \& Mugnai L. (2008): Distribution of Esca Disease in Hungary and the Pathogens Causing the Syndrome Acta Phytopathologica et Entomologica Hungarica, 43 (1): 47-56.

Rego, C., Pádua, M., Carvalho, A. \& Oliveira, H. (1998): Contributo para o estudo da espécie Cylindrocarpon destructans (Zin.) Scholten em material vitícola nacional. Actas 4 Simpósio de Vitivinicultura do Alentejo, May 20-22, Évora, Portugal, 1: 129-135.

Rego, C., Olivera, H., Carvalho, A. \& Philips, A. (2000): Involvement of Phaeoacremonium spp. and Cylindrocarpon deatructans with grapevine decline in Portugal. Phytopathologia Mediterranea. 39: 76-79.

Rego, C., Nascimento, T. \& Oliveira, H. (2001a): Characterisation of Cylindrocarpon destructans isolates from grapevines in Portugal. Phytopathologia Mediterranea 40 (Supplement): S343-S350

Rego, C., Carvalho, A., Nascimento, T. \& Oliveria, H. (2001b): First approach on the understanding of inoculum sources of Cylindrocarpon destructans and Phaeomoniella chlamydospora concerning grapevine rootstocks in Portugal. Bulletin OILB/SROP 24: 67-72.

Rego, C., Farropas, L., Nascimento, T., Cabral, A. \& Oliveira, H. (2006): Black foot of grapevine: sensitivity of Cylindrocarpon destructans to fungicides. Phytopathologia Mediterranea 45 (Supplement): S93-S100

Retief, E., Damm, U., Van Niekerk, J. M., Mcleod, A. \& Fourie, P. H. (2005): A protocol for molecular detection of Phaeomoniella chlamydospora in grapevine wood. South African Journal of Science, 101: 139-142.

Rooney, S. N. \& Gubler, W. D. (2001): Effect of hot water treatments on eradication of Phaeomoniella chlamydospora and Phaeoacremonium inflatipes from dormant grapevine wood. Phytopathologia Mediterranea 40 (Supplement): S467-S472

Rooney, S. N., Eskalen, A. \& Gubler, W. D. (2001): Recovery of Phaeomoniella chlamydospora and Phaeoacremonium inflatipes from soil and grapevine tissues. Phytopathologia Mediterranea 40 (Supplement): S351-S356

Scheck, H. J., Vasquez, S. J. \& Gubler, W. D. (1998): First report of three Phaeoacremonium spp. causing young grapevine decline in California. Plant Disease 82: 590.

Serra, S., Mannoni, M. A., Ligios, V. \& Demontis, A. (2009): Effect of combined hot water and cyprocionazole treatment on the eradication of Phaeomoniella chlamidospora from grapevine planting material. Phytopathologia Mediterranea, 48: 185-186.

Sheck, H., Vasquez, S. J., Fogle, D. \& Gubler, W. D. (1998): Grape growers losses to black-foot and grapevine decline. California Agriculture, 52: 19-23.
Spagnolo, A., Marchi, G., Peduto, F., Phillips, A. \& Surico, G. (2011): Detection of Botryosphaeriaceae species within grapevine woody tissues by nested PCR, with particular emphasis on the Neofusicoccum parvum/N. ribis complex. European Journal of Plant Pathology, 129: 485-500.

Sparapano, L., Bruno, G. \& Graniti, A. (2000): Effects on plants of metabolites produced in culture by Phaeoacremonium chlamydosporum, P. aleophilum and Fomitiporia punctata. Phytopathologia Mediterranea, 39: 169-177.

Surico, G., Mugnai, L. \& Marchi, G. (2008): The ESCA disease complex. in: Ciancio, A. \& Mukerji, K. G., eds. Integrated Management of Diseases Caused by Fungi, Phytoplasma and bacteria, pp.: 119-136.

Surico, G. (2009): Towards a redefinition of the diseases within the esca complex of grapevine. Phytopathologia Mediterranea, 48: 5-10.

Tello, M. L. \& Gonzalez, V. (2010): Evaluation of fungicides for control of Phaeomoniella chlamydospora in soil. Phytopathologia Mediterranea 49: 129. (abstract)

Vajna, L. (1998): A fák nem specifikus betegségek okozta elhalása erdei és gyümölcsös ökoszisztémában (összehasonlító elemzés) Növényxvédelem, 34 (5): 229-240.

Véghelyi K., Balogh I. \& Lukács Gy. (2001): Szőlőtőkék korai pusztulását okozó xilofag taplógombák. Borászati Füzetek, 2: 1-6.

Waite, H. (1998): Hot-water treatment of vinifera and rootstock cuttings. Current status and issues. Interim report of University of Melbourne, Dookie College, Australia

Waite, H. \& May, P. (2005): The effect of hot water treatment, hydration and order of nursery operations on cuttings of Vitis vinifera cultivars. Phytopathologia Mediterranea, 44: 144-152.

Waite, H. \& Morton, L. (2007): Hot water treatment, trunk diseases and other critical factors in the production of high-quality grapevine planting material. Phytopathologia Mediterranea, 46: 5-17.

Wample, R. L., Bary, A. \& Burr, T. J. (1991): Heat tolerance of dormant Vitis vinifera cuttings. American Journal of Enology and Viticulture, 42: 67-72.

White, C., Halleen, F., Fischer, M. \& Mostert, L. (2010): Basidiomycetes and other fungi associated with esca diseased grapevines in South Africa. Phytopathologia Mediterranea, 49: 103-104.

Whitelaw-Weckert, M. A. (2010): Interaction between Cylindriocarpon and glyphosate in young vine decline. Phytopathologia Mediterranea, 49: 117-1180.

Whiteman, S. A., Jaspers, M., Stewart, A. \& Ridgway, H. (2002): Detection of Phaeomoniella chlamydospora in soil using species-specific PCR. New Zealand Plant Protection, 55: 139-145.

Whiteman, S. A., Stewart, A., Ridgway, H. J. \& Jaspers, M. (2007): Infection of rootstock mother-vines by Phaeomoniella chlamydospora results in infected young grapevines. Australasian Plant Pathology, 36: 198-203.

Whiting E. C., Khan, A. \& Gubler, W.D. (2001): Effect of temperature and water potential on survival and mycelial growth of Phaeomoniella chlamydospora and Phaeoacremonium spp. Plant Disease, 85:195-201.

Zanzotto, A., Serra, S., Viel, W. \& Borgo, M. (2001): Investigation the occurence of esca-associated fungi in cuttings and bench-grafted vines. Phytopathologia Mediterranea, 40: S311-S316. 